\title{
PUBLIC ENTERPRISES AND TAXATION ISSUES WITHIN THE FRAMEWORK OF TURKISH CORPORATE TAX
}

\author{
Erkan AYDIN ${ }^{1}$
}

\begin{abstract}
On top of their main purpose of delivering public service, it is possible for the public administrations and public institutions to establish economic enterprises in order to engage commercial, industrial and agricultural activities. In this respect, as per the Article 2 of the Corporate Tax Law No. 5520, the public enterprises are considered as corporate taxpayers. The main reason behind the taxation of public enterprises is to avoid competitive distortions between public and private enterprises. Therefore, public enterprises should not seek profit but engage with the enacted activities. Also, public enterprises are unincorporated entities that are considered as corporate taxpayers even in the absence of independent accounting, dedicated capital or business office. However, as per the Article 4 of the Corporate Tax Law, the public administrations and public institutions that are engaging in activities such as education, health, social welfare, culture and art are exempt from corporate tax.

Public enterprises gain assests depending on their emergence as an economic enterprise in accordance with their activities. Economic enterprises emerge as a result of permanent commercial, industrial and agricultural activities. However, sometimes there are different opinions on under which circumstances a public enterprise becomes an economic enterprise as far as the tax applications are concerned.

In this regard, there are sometimes issues on determining under which circumstances the enterprises with revolving capital are not exempt from corporate tax and if their activities form an economic enterprise. Similarly, there are sometimes issues on determining if the activities of the community facilities that are run by public administrations and public institutions breaching the conditions of corporate tax exemption. In addition, it is also an arguable issue that the economic enterprises that are owned by professional organisations that are legal entities with the status of a public institution are considered within the scope of the enterprises owned by assosications, whilst not regarded as public enterprises in terms of tax applications.
\end{abstract}

Keywords: Public enterprises, economic enterprise, revolving capital, corporate tax, taxation issues

JEL Code: H2O, H25, K34

\section{Introduction}

Public administrations and public institutions have the common purpose of providing public services in order to meet public needs. It is also possible for public administrations and public institutions to establish economic enterprises. After taking this into account, public enterprises are regarded as corporate taxpayer as per the Article 2 of the Corporate Tax Law No. 5520. Furthermore, the Article 4 of the Corporate Tax Law holds the public administrations and public institutions that are delivering common public services exempt from corporate tax.

The main reason that public enterprises are considered as a taxpayer is to avoid unfair competition with the private enterprises. It is natural for public enterprises to be considered as a corporate

\footnotetext{
${ }^{1}$ Prof. Dr., Marmara University, Faculty of Economics, Department of Public Finances, erkanaydin@marmara.edu.tr
} 
taxpayer as their activities are on the same level with private enterprises even though the main purpose of public enterprises is not to gain profit.

In order for a public enterprise exist, the economic enterprise has to emerge as a result of their activities. An economic enterprise emerges as a result of permanent commercial, industrial and agricultural activities. However, there are sometimes disputes on under which circumstances the private enterprises emerge according to the application of corporate tax.

In this study, firstly, the concept of public enterprise as per the Corporate Tax Law will be explained and compared to similar concepts. Secondly, how public enterprises emerge within public administrations and public institutions will be detailed. And then, the issues on corporate taxation of revolving funds, social facilities owned by the public administrations and public institutions, prison workshops, public professional organisations and finally economic enterprises owned by foreign countries will be discussed in the light of administrative reviews and judicial decisions.

\section{Public Enterprises}

\subsection{The Concepts of the Public Enterprises and the Economic Public Enterprises}

Article 2 of the Executive Order No. 233 identifies public economic enterprise as the common name of state economic enterprise and public economic organisation. State economic enterprise is defined as a public economic enterprise that operates in accordance with commercial principals and its shares are fully owned by the state. However, public economic organisation is defined as an organisation that is established in order to solely-provide certain goods and services and its shares are fully owned by the state.

The concept of public enterprise is described as wider than state economic enterprise and it also includes the economic enterprises that are out of state economic enterprise in the Corporate Tax Law (Oluş-Özbalcı Mali Hukuk Bürosu, 2012: 69; Sezgin, 2014: 44; Tekin\& Kartaloğlu, 2010: 45; Arpacı, 2016: 35).

\subsection{The Necessities for Being a Public Enterprise}

As per the Article 2 of the Corporate Tax Law, public enterprises are owned by the state, provincial special administrations and other public administrations and public institutions. They are defined as "commercial, industrial and agricultural enterprises" of continuous operation outside of equity companies and cooperatives. Ownership here means the capital ownership and the affiliation means the administrative affiliation according to the No.1 General Communiqué of Corporate Tax.

The purpose of the taxation of the public enterprises is to avoid any unfair competition in the free market against private enterprises by granting the public enterprises tax privilege (Maç, 1999: 14; Şenyüz, 2007: 22; Uysal \& Eroğlu, 2008: 92; Ürel, 2009: 13). Thus, their tax obligation is not affected by not seeking profit, their activities are enacted as duties, being unincorporated. Also, non-existence of independent accounting and reserved capital or any business offices do not affect their tax obligation. Furthermore, the public enterprises still cannot avoid tax obligation in the event of total cost and total revenue of the goods and services being equal or failing to profit, using the profit for the founding purpose, the public enterprises still cannot avoid tax obligation. 


\subsection{The Conditions for the Existence of Economic Enterprise Owned by Public Instution}

An economic enterprise owned by a public enterprise is determined under certain conditions. According to the No.1 General Communiqué of Corporate Tax, in order to determine a public enterprise which establishes a commercial, industrial or agricultural enterprises, the regulations concerning the enterprises owned by associations and foundations will be taken into account.

While conducting activities such as production or trade of goods or performing services under the principles of free market economy as part of a continuous and certain organisation, an economic enterprise is determined. (Oluş-Özbalcı Mali Hukuk Bürosu, 2012: 71; Semercigil, 1995: 22-23; Sezgin, 2014: 45). The transfer of the income gained by public enterprises to the Treasury does not effect the existence of public enterprises. On this matter, a cafeteria that is run as a public enterprise of a revolving fund and the transfer of its income to the Treasury will not change the existance of the commercial activity according to the decision of the General Assembly of Tax Courts of the Council of State ${ }^{2}$. However, in the event of gaining incidental income or income from movable and immovable assets, the existence of a public enterprise cannot be claimed. (Maç, 1999: 16; Uysal \& Eroğlu, 2008: 96). Thus, a related decision of the Council of State states that the rental income through the municipality's immovable assets cannot be considered as a commercial income ${ }^{3}$.

\section{Taxation Issues Of The Public Enterprises}

\subsection{Corporate Tax Obligation of the Revolving Funds}

Article 3 of the Budget and Accounting Directive for the Revolving Funds defines the revolving funds as the funds that are assigned to the enterprises that are established by the public administrations in order to operate to provide services and goods that are within the scope of their duties but impossible to perform under the general administrative principles.

The revolving funds are considered as public enterprise as per No.1 General Communiqué of Corporate Tax. Also, tax exemption applies to the public administrations and public institutions that are active in education, health, social welfare, culture, and art under the Article 4/ (1) of the Corporate Tax Law. However, in case of operating continuously commercial, industrial, and agricultural activities without the mentioned objectives, the revolving funds become corporate taxpayers (Beylik, 2010: 47). This is applicable to the activities within universities. Therefore, the income delivered by the revolving funds or continuing education centres from the activities that falls outside the scope of these objectives are to be taxed (Uzunoğlu, 2015: 23).

In this regard, a ruling issued by tax administration regulates economic enterprises that emerged after the sale of project development, consultancy, analysis and surveying services, the revolving funds as public funds become corporate taxpayers ${ }^{4}$. A cafeteria owned by the revolving fund of

\footnotetext{
2 The General Assembly of Tax Courts of the Council of State Decision, Date: 27.02.2004, Case No: 2003/331, Decision No: 2004/18, www.legalbank.net/MusePath/belge/d-vddk-e-2003-331-k-2004-18-t-27-02-2004-danistayvergi-dava-daireleri-kurulu-karari/623171 (Accessed on: 12.01.2019)

$33^{\text {rd }}$ Chamber of the Council of State Decision, Date: 07.02.2012, Case No: 2010/3441, Decision No: 2012/304, www.legalbank.net/MusePath/belge/d-3-d-e-2010-3441-k-2012-304-t-07-02-2012-belediyeye-ait-gayrimenkulsermaye-iradi-kapsamina-giren-k/1409705 (Accesed on: 14.12.2018)

4 Istanbul Tax Department, The Ruling, Date: 11.06.2015, No: 62030549-125[2-2014/266]-60309, http://www. gib.gov.tr/doner-sermaye-isletme-mudurlugunun-kurumlar-vergisi-mukellefiyeti (Accesed on: 13.01.2019)
} 
an educational institution is considered as an economic enterprise and consequently regarded as a corporate taxpayer as per the aforementioned decision of the General Assembly of Tax Courts of the Council of State. On a contrary decision, the General Assembly of Tax Courts of the Council of State ruled that the corporate tax obligation does not occur for facilities of occupational skill training for the students of vocational schools of tourism and hotel management ${ }^{5}$.

\subsection{The Social Facilities Owned by the Public Administrations and Public Institutions}

It is known that some social facilities that are run by public administrations and public institutions provide services to non-civil servants as well. According to the Article 4/(1)-d of the Corporate Tax Law, public administration's nurseries, guest houses, and canteens of the military barracks that serve solely to the public servants are exempt from the corporate tax. The state institutions and organizations within the scope of the general management, such as the regulatory and auditing institutions, social security institutions, and nurseries and guest houses owned by the local institutions can also benefit from this exemption as per the General Communiqué.

Social facilities owned by public organisations need to be considered as economic enterprises once their services are provided to non-members of those facilities (Arslan 2016: 120). Furthermore, they need to be considered in breach of the conditions of exemption in case their service exceeds purpose of meeting the necessary needs. In a related ruling, it is stated that state-owned accommodation facilities are to become corporate taxpayers in case their services exceed the necessary services such as accommodation and food for public servants ${ }^{6}$. However, the Council of State ruled that it is not possible to hold the non-profit social facilities responsible for corporate tax for their services they operate to survive ${ }^{7}$.

Additionally, according to the General Communiqué canteens that are established for the sale of necessary goods for soldiers are exempt from the corporate tax. Since the Military Canteens Directive does not include such limitation, there is an incompatibility between the military and tax legislation on this matter. Also, the limitation of tax exemption by a general communiqué on a tax exemption delivered by the Corporate Tax Law creates uncertainties on the tax applications (Topsakal, 227: 240).

\subsection{Corporate Tax Exemption of Prison Workshops}

As per the Article 4/(1)-c of the Corporate Tax Law, workshops of penal and hospice institutions are exempt from the corporate tax. Moreover, Section 4.3.2 of the No 1. General Communique of Corporate Tax classifies canteens and car parks owned by the workshops as economic enterprises and considers them corporate taxpayers. However, the Council of State reversed this regulation as the mentioned exemption is not subjected to a condition ${ }^{8}$.

\footnotetext{
${ }^{5} 4^{\text {th }}$ Chamber of the Council of State Decision, Date: 21.12 .2015 , Case No: $2015 / 10087$, Decision No: $2015 / 7548$ (Personal Archive)

6 Ankara Tax Department, The Ruling, Date: 19.08.2011, No: B.07.1.GiB.4.06.16.01-2011-KVK-1-3-627, www. lexpera.com.tr/mevzuat/ozelgeler/GE801D20110819HM1634431965 (Accessed on: 08.02.2019)

$74^{\text {th }}$ Chamber of the Council of State Decision, Date: 27.01.2014, Case No: 2010/5519, Decision No: 2014/447 (Personal Archive)

8 The General Assembly of Tax Courts of the Council of State Decision, Date: 16.04 .2010 , Case No: 2008/783, Decision No: 2010/200, www.kazanci.com/MusePath/kho2/ibb/files/dsp.php?fn=vddgk-2008-783.htm\&kw='2008/783`\#fm (Accessed on: 14.01.2019)
} 


\subsection{Enterprises Owned by the Public Professional Organisations}

Public professional organisations are respected as public legal entities under the Article 135 of the Constitution. These institutions are exempt from tax for the income that is delivered as part of the activities that are enacted by law as duties. However, they will become corporate taxpayers after their activities outside their duties and purposes cause them to become an economic enterprise. An economic enterprise will emerge in case of the permanent and tollable activities of the occupational associations that delivers income from third parties as the Council of State rule?

In this respect, since the professional organisations are considered as public intiutitons, it is conceivable to state that their economic enterprises need to be considered as public enterprises (Paklar, 1987: 64). However, the Council of State ruled that the economic enterprises owned by the public professional organisations are subjected to the laws that are applicaple to the enterprises owned by the assosications ${ }^{10}$.

\subsection{Economic Enterprises Owned by Foreign Countries}

As per the Article $2 /(4)$ of the Corporate Tax Law, the commercial, industrial and agricultural enterprises outside the scope of capital companies and cooperatives that are owned by foreign countries or foreign administration and institutions are also subjected to corporate tax as are the ones owned by the Turkish public administrations and public institutions. In this regard, the economic activities of the foreign representatives over the limits of the diplomatic represenatation also needs to be subjected to the corporate tax (Abay, 2013: 54).

In case of the permanent commercial, industrial or agricultutal activities of the foreign countries or foreign administration and institutions, an economic enterprise will be formed and consequently the corporate tax obligation will occur. Thus, the ruling on this matter states that the offices of the foreign countries are not corporate taxpayers unless these offices involve any commercial, industrial or agricultural activities in Turkey ${ }^{11}$.

\section{Conclusion}

Public enterprises are the economic enterprises owned by the public administrations and public institutions. The Corporate Tax Law has detailed the concept of the public enterprises and included the enterprises that are not classified as the public economic enterprises.

The public enterprises are regarded as the corporate tax payers in order to avoid unfair competition against other enterprises that are operating under the same economic conditions. It does not hold a public enterprise to become a corporate tax payer even if they are not seeking profit, operating solely for the duties given by the law, possess legal entity, and having an independent accounting and dedicated capital or offices.

\footnotetext{
$93^{\text {rd }}$ Chamber of the Council of State Decision, Date: 24.11.2008, Case No: 2007/3869, Decision No: 2008/3718, www.legalbank.net/MusePath/belge/d-3-d-e-2007-3869-k-2008-3718-t-24-11-2008-turk-muhendis-ve-mimarodalasi-gerlilerinin-kurumlar-verg/648608 (Accessed on: 04.01.2019)

$109^{\text {th }}$ Chamber of the Council of State Decision, Date: 17.06.2008 Case No: 2007/6016, Decision No: 2008/3170, www.legalbank.net/MusePath/belge/d-9-d-e-2007-6016-k-2008-3170-t-17-06-2008-vergi-odevi/623021 (Accessed on: 04.01.2019)

${ }^{11}$ General Directorate of Revenues, The Ruling, Date: 15.06.1999, No: b.07.0.GEL.0.87/8734/24224, www.gib.gov. $\mathrm{tr} / \mathrm{node} / 97636$ (Accessed on: 08.02.2019)
} 
A public enterprise can only exists as after an economic enterprise emerges. An economic enterprise on the other hand, becomes as a result of permanent commercial, industrial or agricultural activity through a specific organisation. Therefore, the income stemmed from an temporary activities or moveable or immovable properties does not consititute the economic enterprise.

For the application of corporate tax, there are noted differences between administrative and judicial opinions on the requirements of an enterprise to be considered as a public enterprise. In this regards, there are difficulties on how to identify the activities of the revolving funds that establish a corporate taxpayer enterprise. It is also disputable whether or not to consider the enterprises owned by the public professional organisations as public enterprise and regard them within the scope of the enterprise owned by the assosciations.

\section{References}

\section{Journals/Periodicals}

Abay, K. (2013). "Ülkemizde Bulunan Yabancı Diplomatik Temsilciliklere Ait İktisadi İşletmelerin Mükellefiyet Durumu”, Vergi Dünyası, S.381, Mayıs, 2013, ss.49-54.

Arpacı, A.Ö. (2016). "iktisadi Kamu Kuruluşlarının Kurumlar Vergisi Mükellefiyeti”, Vergici ve Muhasebeciyle Diyalog, S.344, Aralık, 2016, ss.31-39.

Arslan, A. (2016). "Sosyal Tesislerin KDV ve Kurumlar Vergisi Karşısındaki Durumu”, Vergi Dünyası, S.422, Ekim, 2016, ss.117-121.

Beylik, A. (2010). “Döner Sermayeli İşletmelerin Vergilendirilmesi-II”, Vergi Dünyası, S.345, Mayıs, 2010, ss.42-47.

Topsakal, M. (2015). “Askeri Sosyal Tesislerle İlgili Mevzuat Hükümlerinin Kurumlar Vergisi Karşısındaki Durumu”, Inönü Üniversitesi Hukuk Fakültesi Dergisi, C.6, S.1, 2015 ss.227-247.

Uzunoğlu, N. (2015). "Üniversitelere Ait Döner Sermayeler ve Sürekli Eğitim Merkezleri Aracılığı ile Verilen Hizmetlerin Kurumlar Vergisi Muafiyeti ve Uygulanacak KDV Oranına Etkisi", Vergi Dünyası, S.411, Kasım, 2015, ss.19-29.

\section{Books}

Maç, M. (1999). Kurumlar Vergisi, 3.Baskı, İstanbul, Denet Yayıncılık.

Oluş-Özbalcı Mali Hukuk Bürosu (2012). Kurumlar Vergisi Kanunu Yorum ve Açıklamaları, Ankara.

Paklar, S. (1987). Kurumlar Vergisi Kanunu Yorum ve Uygulaması, 2.Baskı, İstanbul.

Semercigil, M. (1995). Kurumlar Vergisi Kanunu ve Açıklamaları, Ankara.

Sezgin, B. (2014). Kurumlar Vergisi Kanunu Yorum ve Açıklamaları, 1.Baskı, Ankara, Adalet Yayınları.

Şenyüz, D. (2007). Açıklama ve Yorumlu 5520 Sayılı Kurumlar Vergisi Kanunu, Ankara, Yaklaşım Yayıncilık. 
Tekin, C. \& Kartaloğlu, E. (2010). Kurumlar Vergisi Kanunu Yorum ve Açıklamaları, 2.Baskı, İstanbul, Denetim Turkey Yayınları.

Uysal, A. \& Eroğlu, N. (2008). Açıklamalı ve Örnekli Kurumlar Vergisi Kanunu, 2.Baskı, Ankara.

Ürel, G. (2009). Yeni Kurumlar Vergisi Kanunu Uygulaması, Ankara, Maliye ve Hukuk Yayınları. 